\title{
Relationship between the abundance and distribution of the endemic fish Paretroplus dambabe in the north-western wetland of Madagascar and the effect of environmental parameters and the presence of other fish species
}

\begin{abstract}
Paretroplus dambabe is a local endemic fish species only found in Kinkony Lake (in north-western wetland and protected area) and two surrounding small lakes, Andranobe and La Digue. The ecology of $P$. dambabe is threatened by the human activities that cause the erosion and decrease of reed vegetation surface. Also, the lake is undergoing ricegrowing in the shore. In addition, the invasive fish species could affect the distribution of $P$. dambabe. This study aims to determine the influence of the physic-chemical parameters, reed vegetation and the other fish species on the abundance of $P$. dambabe. Three categories of variables were taken into account: (a) the physic-chemical parameters, (b) the distance from the reed vegetation, and (c) the number of fish species and the relative abundance per sampling station of each fish species. Environmental variables and the presence of the Tilapiinae cichlids do not yet affect the presence of $P$. dambabe in the Kinkony Lake. But, the abundance of this endemic fishis negatively and significantly influenced by the abundance of the common carp Cyprinus carpio, Ambassis sp., sleepy goby Glossogobius biocelatus, tank goby G. giuris, longfin tilapia Oreochromis macrochir, Nile tilapia $O$. niloticus, Mozambic tilapia O. mossambicus, redbreast tilapia Tilapia rendalli and redbelly tilapia $T$. zillii. Species within the genera Oreochromis and Tilapia, and C. carpio could eat the eggs of $P$. dambabe when they consume the aquatic plant in the lake. Species within the genus Glossogobius are carnivorous species and could eat the juvenile of $P$. dambabe. As $P$. dambabe, A. sp. is an omnivorous species and could be in competition with P. dambabe. Thus, the manager of this north-western protected area (Mahavavy-Kinkony Complex) should continue the ecological monitoring of the lake to observe the evolution of the physic-chemical parameters, the surface of the reed vegetation and the abundance of native and invasive species. Climate change can disturb the environmental parameters of Kinkony Lake and could affects native fish species compared to the invasive species.
\end{abstract}

Keywords: Paretroplus dambabe, abundance, environmental parameters, freshwater fishes, kinkony lake, north-western, wetland, Madagascar
Volume 2 Issue 2 - 2018

Ramanantsalama RV,Andriamasimanana RH, Andrianarimisa A, Oliarinony $R$

Zoology and Animal Biodiversity Department, University of Antananarivo, Madagascar

Correspondence: Oliarinony R, Zoology and Animal Biodiversity Department, Faculty of Sciences, University of Antananarivo, PB 906, Ankatso, Antananarivo I01, Madagascar, Email ranalison.oliarinony@gmail.com

Received: February 13, 2018| Published: April 02, 2018

\section{Introduction}

The endemic Malagasy cichlid Paretroplus dambabe Sparks 2002 is a local endemic fish species located in Kinkony Lake $\left(16^{\circ} 05^{\prime} \mathrm{S}\right.$, $45^{\circ} 52^{\prime} \mathrm{E}$ ), in the north-western wetland and protected area of Madagascar, and two surrounding small lakes Andranobe $\left(16^{\circ} 09^{\prime} \mathrm{S}\right.$, $\left.45^{\circ} 42^{\prime} \mathrm{E}\right)$ and La Digue (16 $\left.09^{\prime} \mathrm{S}, 45^{\circ} 42^{\prime} \mathrm{E}\right)$. Paretroplus dambabe prefers deep freshwater and lives only in a habitat where the water is lukewarm and briny. ${ }^{1}$ It is an omnivorous species and this species is more sensitive to any kind of disturbance in term of salinity compared to the other cichlids species. ${ }^{2,3}$ This last decade, Kinkony Lake ecosystem is disturbed by erosion and the conversion of the shore into rice-growing land. The lake is also threatened by sedimentation from the erosion of Mahavavy watershed and the other rivers that could increase the water salinity and $\mathrm{pH}$. Furthermore, the invasive species especially the tilapiine cichlids could also disturb the ecology of the native species in the Lake., ${ }^{4,5}$ The tilapiine cichlids grow and breed quickly compared to the native fish species. ${ }^{3}$ Prior researches show the capacity of tilapiine cichlids to live in water with temperature above $35^{\circ} \mathrm{C} .6,7$ The member of this invasive subfamily is able to survive with $35 \%$ salinity, however the maximum lethal salinity for P. dambabe is $10 \%{ }^{2}{ }^{2}$ Frei et al. ${ }^{8}$ state that combination of species within the tilapiine cichlids and the common carp Cyprinus carpio negatively impacts native macrophyte. This could impact native fish species ecology that uses macrophyte for spawning and foraging. ${ }^{9}, 10$ Moreover, previous studies state that the main threat for P. dambabe could be the reduction of reed vegetation surface that was losing $80 \%$ of its surface since 1949 through 2008..$^{11,12}$ Paretroplus dambabe could use the reed vegetation at Makary site to lay their eggs and this habitat also gives nutrients especially for fish that feeds on microorganisms and suspended matters. ${ }^{5}$ So, this study aims to determine the effect of the physic-chemical parameters spatial variation and the influence of the other fish species on the presence and abundance of $P$. dambabe. Also, it analyses if the distribution of $P$. dambabe is related to the reed vegetation. Therefore, the hypothesis of this study is that the spatial variation of the physic-chemical parameter, the presence of the 
other fish species and the distance from the reed vegetation affect the presence and the relative abundance of $P$. dambabe.

\section{Materials and methods}

\section{Preliminary study}

Actually, sampling should cover all the part of the lake so that the modeling could have minimum of error. Also, the number of station in each site depended on the surface where fishing was feasible. So, map and shape file of Kinkony Lake from Asity Madagascar association were used to find some points that will represent stations of data sampling. The geographical coordinate of these points were imported into a Global Positioning System (GPS) to indicate automatically the station location in the field. Moreover, data regarding reed vegetation repartition and surface in Kinkony Lake were obtained from Asity Madagascar database as well.

\section{Study site}

Sampling was conducted in 10 September to 5 October 2014 in Kinkony Lake, Ramsar site located within the protected area of Mahavavy-Kinkony Wetland Complex, in the north-western area of Madagascar. ${ }^{13}$ As shown below (Figure 1), all sampling stations were spread over five sites in Kinkony Lake: (a) Bevoay $\left(16^{\circ} 08^{\prime} \mathrm{S}\right.$, $\left.45^{\circ} 45^{\prime} \mathrm{E}\right)$, (b) Tombomafana (16 $\left.10^{\circ} \mathrm{S}, 4^{\circ} 50^{\prime} \mathrm{E}\right)$, (c) Makary $\left(16^{\circ} 09^{\prime} \mathrm{S}, 45^{\circ} 54^{\prime} \mathrm{E}\right),(\mathrm{d})$ Antongomenabe $\left(16^{\circ} 08^{\prime} \mathrm{S}, 45^{\circ} 53^{\prime} \mathrm{E}\right)$ and (e) Marofandroboka ( $\left(6^{\circ} 05^{\prime} \mathrm{S}, 45^{\circ} 51^{\prime} \mathrm{E}\right)$.

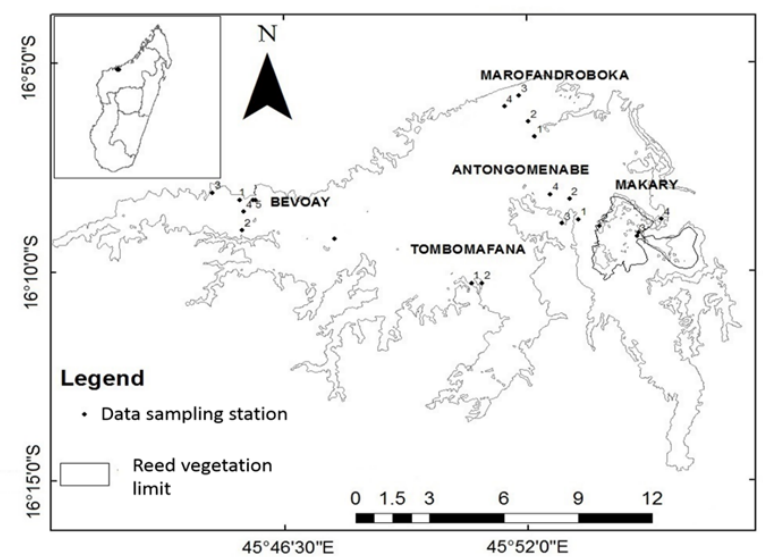

Figure I Data sampling stations in the Kinkony Lake. The site of Bevoay has six stations of data sampling (Bevoay I, Bevoay2, Bevoay3, Bevoay4, Bevoay5 and Bevoay6),Tombomafana has two stations (Tombomafanal and Tombomafana2), Marofandroboka has four stations (Marofandrobokal, Marofandroboka2, Marofandroboka3 and Marofandroboka4), there are four data sampling stations in Antongomenabe (Antongomenabel, Antongomenabe2, Antongomenabe3 and Antongomenabe4) and the site of Makary is constituted by four stations (MakaryI, Makary2, Makary3 and Makary4).

\section{Data sampling}

Water parameter data such as the water temperature, turbidity,
$\mathrm{pH}$, redox potential, dissolved oxygen and conductivity were taken at 6 hours in the morning. Water turbidity in Nephelometric Turbidity Unit (NTU) is measured by electronic turbidimeter (WGZ-1). Water temperature in Celsius degree $\left({ }^{\circ} \mathrm{C}\right), \mathrm{pH}$, redox potential in millivolt $(\mathrm{mV})$, dissolved oxygen in milligram per liter $\left(\mathrm{mg} \mathrm{l}^{-1}\right)$ and conductivity in microsiemens $(\mu \mathrm{S})$ were collected using an electronic device called SX736.

Gill net with $100 \mathrm{~m}$ length, $1 \mathrm{~m}$ width and $20 \mathrm{~mm}$ mesh is used to collect the quantitative and qualitative data regarding all fish species. The net was been setting up from 06 hours to 11 hours every day during two days per station. In this study, relative abundance (Ar) can be defined as the percentage of collected individuals of one species in relation to all collected individuals of all species in Kinkony Lake. Depending on the value of $\mathrm{Ar},{ }^{14}$ one species can be classified as dominant $(\mathrm{Ar} \geq 15 \%)$, influential $(5 \% \leq \mathrm{Ar} \leq 15 \%)$, rare $(1 \% \leq \mathrm{Ar} \leq 5 \%)$ and very rare $(\mathrm{Ar} \leq 1 \%)$. The relative abundance per station (Ars) which is defined as the number of collected individuals of one species per station divided to the number of all collected individuals of all species in this station, is also calculated to quantify the number of individuals of each fish species per station in the lake.

\section{Data analysis}

Factor analysis and Spearman bivariate correlation were used to outline the collinear independent variables. Only one of the collinear independent variables should be chosen to be included in the linear model. Then, the influence of retained independent variables on the presence and relative abundance of $P$. dambabe, were analyzed using the multiple linear regression (MLR). Akaike's information criterion (AIC) value of each model was employed to select the best model. Factor analysis and MLR were undertaken under the R 3.4 programme which is assessed with the help of RStudio. ${ }^{15-18}$ The model selection was possible thanks to the "car", "hier. part", "MASS", "MuMIn", "leaps" and "Hmisc" R packages. The Spearman bivariate correlation was performed using SPSS software. ${ }^{19}$

\section{Results}

\section{Physical and chemical property of kinkony lake}

The physical and chemical properties of all stations located in one site do not show any significant difference. Hence, physical and chemical variable value of one site is the average of the collected values of this variable in this site (Table 1). Marofandroboka is the site with the highest value of temperature. Moreover, the water is moderately saline throughout the lake. However, among the five sites, Tombomafana is less saline contrary to Makary. Regarding to all $\mathrm{pH}$ value, the water of the lake is basic. There are no significant differences between the $\mathrm{pH}$ of all sites and it is the same case for the dissolved oxygen rate. For the turbidity, the water at Makary and Antongomenabe are both slightly unclear and the three other sites are unclear. Makary has the lowest value of turbidity and Tombomafana has the most unclear water. All the redox potential values in Kinkony Lake are negative, i.e. the water of the lake is reducer. Bevoay has the lowest value of redox potential contrary to Makary. 
Table I Characteristic of the water at each site according to the water physical and chemical property

\begin{tabular}{|c|c|c|c|c|c|}
\hline site & Antongomenabe & Bevoay & Tombomafana & Makary & Marofandroboka \\
\hline $\begin{array}{l}\text { Number of } \\
\text { stations }\end{array}$ & 4 & 6 & 2 & 4 & 4 \\
\hline $\mathrm{pH}$ & $8.84 \pm 0.06$ & $8.82 \pm 0.16$ & $8.76 \pm 0.12$ & $8.20 \pm 0.29$ & $8.82 \pm 0.04$ \\
\hline $\begin{array}{l}\text { Dissolved } \\
\text { oxygen }\end{array}$ & $16.41 \mathrm{mg} \mathrm{l}^{-1} \pm 0.07 \mathrm{mg} \mathrm{|}^{-1}$ & $16.72 \mathrm{mg} \mathrm{l}^{-1} \pm 0.21 \mathrm{mg} \mathrm{l}^{-1}$ & $16.5 \mathrm{Img} \mathrm{I} \pm 0.01 \mathrm{mg} \mathrm{l}^{-1}$ & $16.50 \mathrm{mg} \mathrm{l}^{-1} \pm 0 \mathrm{mg} \mathrm{l}^{-1}$ & $16.50 \mathrm{mg} \mathrm{l}^{-1} \pm 0 \mathrm{mg} \mathrm{l}^{-1}$ \\
\hline Turbidity & $29.01 \mathrm{NTU} \pm 8.8 \mathrm{INTU}$ & $43.98 \mathrm{NTU} \pm$ I $5.98 \mathrm{NTU}$ & 53.54 NTU $\pm 1.73 \mathrm{NTU}$ & 26.2 INTU $\pm 8.18 \mathrm{NTU}$ & $52.79 \mathrm{NTU} \pm 13.79 \mathrm{NTU}$ \\
\hline Redox potential & $-109.85 \mathrm{mV} \pm 3.97 \mathrm{mV}$ & $-109.93 \mathrm{mV} \pm 4.0 \mathrm{ImV}$ & $-104.74 \mathrm{mV} \pm 6.77 \mathrm{mV}$ & $-70.24 \mathrm{mV} \pm 18.95 \mathrm{mV}$ & $-108.00 \mathrm{mV} \pm 3.24 \mathrm{mV}$ \\
\hline Conductivity & $296.40 \mu S \pm 20.89 \mu S$ & $260.11 \mu S \pm 12.12 \mu S$ & $244.81 \mu S \pm I .17 \mu S$ & $347.15 \mu \mathrm{S} \pm 24.20 \mu \mathrm{S}$ & $263.50 \mu S \pm 5.58 \mu S$ \\
\hline
\end{tabular}

\section{Caught species and individuals and relative abundance}

Makary and Antongomenabe have the highest value in term of number of caught fish species. Tombomafana, Bevoay and Marofandroboka have the highest number of captured individuals (Table 2). The long fin tilapia Oreochromis macrochir, the Nile tilapia Oreochromis niloticus and the Mozambique tilapia Oreochromis

Table 2 Number of caught species and individuals per station mossambicus are the dominant species in Kinkony Lake (Table 2). The red belly tilapia Tilapia zillii, the redbreast tilapia Tilapia rendalli, Ambassis sp. and $P$. dambabe are influential. The tank goby Glossogobius giuris is a rare species and the sleepy globy Glossogobius biocellatus and C. carpio are very rare. There are actually two caught individuals of C. carpio in the lake but the relative abundance is really small and rounded off to $0 \%$.

\begin{tabular}{|c|c|c|c|c|c|c|c|c|c|c|c|c|c|}
\hline Stations & $\begin{array}{l}\text { Caught } \\
\text { individuals }\end{array}$ & $\begin{array}{l}\text { Caught } \\
\text { individuals }\end{array}$ & $\begin{array}{l}\text { Species } \\
\text { number }\end{array}$ & $\begin{array}{l}P . \\
\text { dambabe }\end{array}$ & $\begin{array}{l}\text { O. } \\
\text { mossambicus }\end{array}$ & $\begin{array}{l}\text { O. } \\
\text { macrochir }\end{array}$ & $\begin{array}{l}\text { O. } \\
\text { niloticus }\end{array}$ & $\begin{array}{l}T . \\
\text { rendalli }\end{array}$ & $\begin{array}{l}T . \\
\text { zillii }\end{array}$ & $\begin{array}{l}\text { C. } \\
\text { carpio }\end{array}$ & $\begin{array}{l}\text { A. } \\
\text { sp. }\end{array}$ & $\begin{array}{l}\text { G. } \\
\text { giuris }\end{array}$ & $\begin{array}{l}\text { G. } \\
\text { biocellatus }\end{array}$ \\
\hline Bevoayl & 27 & & & 4 & 8 & 6 & 0 & 0 & 9 & 0 & 0 & 0 & 0 \\
\hline Bevoay2 & 15 & & & 4 & 0 & 5 & 0 & 0 & 6 & 0 & 0 & 0 & 0 \\
\hline \multirow[t]{2}{*}{ Bevoay3 } & 26 & & & 0 & 5 & 5 & 6 & 0 & 10 & 0 & 0 & 0 & 0 \\
\hline & & 106 & 8 & & & & & & & & & & \\
\hline Bevoay 4 & 27 & & & 0 & 11 & 15 & 1 & 0 & 0 & 0 & 0 & 0 & 0 \\
\hline Bevoay5 & 6 & & & 1 & 0 & 0 & 1 & 0 & 2 & 0 & 2 & 0 & 0 \\
\hline Bevoay6 & 5 & & & 1 & 0 & 0 & 1 & 1 & 1 & 0 & 0 & 1 & 0 \\
\hline \multirow[t]{2}{*}{ Tombomafanal } & 19 & & & 3 & 7 & 3 & 0 & 0 & 1 & 0 & 5 & 0 & 0 \\
\hline & 15 & 34 & 6 & 0 & 11 & 1 & 0 & 0 & 1 & 0 & 1 & 1 & 0 \\
\hline Makaryl & 34 & & & I & 13 & 0 & 7 & 9 & 2 & 0 & 0 & 0 & 2 \\
\hline \multirow[t]{2}{*}{ Makary2 } & 35 & & & 1 & 0 & 8 & 4 & 8 & 9 & I & 4 & 0 & 0 \\
\hline & 10 & 96 & 10 & 2 & 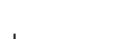 & & 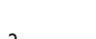 & & & & & & 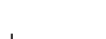 \\
\hline Makary3 & 18 & & & & & & & & & & & & \\
\hline Makary4 & 9 & & & 0 & 2 & 0 & 5 & 0 & 0 & 0 & 0 & 2 & 0 \\
\hline Antongomenabe I & 9 & & & 0 & 0 & 3 & 2 & 2 & 0 & 0 & 0 & 0 & 2 \\
\hline \multirow[t]{2}{*}{ Antongomenabe2 } & 24 & & & 2 & 0 & 12 & 7 & 2 & 1 & 0 & 0 & 0 & 0 \\
\hline & & 60 & 10 & & & & & & & & & & \\
\hline Antongomenabe3 & 1 & & & 0 & 0 & 0 & 0 & 1 & 0 & 0 & 0 & 0 & 0 \\
\hline Antongomenabe 4 & 26 & & & 1 & 2 & 12 & 4 & 2 & 1 & I & 2 & 1 & 0 \\
\hline Marofandrobokal & 20 & & & 0 & 0 & I & 9 & 2 & 0 & 0 & 7 & 1 & 0 \\
\hline \multirow[t]{2}{*}{ Marofandroboka2 } & 58 & & & 0 & 0 & 21 & 33 & 2 & I & 0 & 0 & I & 0 \\
\hline & & 106 & 9 & & & & & & & & & & \\
\hline Marofandroboka3 & 5 & & & 1 & 0 & 3 & 0 & 0 & 0 & 0 & 0 & 0 & 1 \\
\hline \multirow[t]{3}{*}{ Marofandroboka4 } & 23 & & & 1 & 4 & 5 & 8 & 3 & 0 & 0 & 1 & 1 & 0 \\
\hline & 402 & 402 & & 23 & 64 & 103 & 90 & 37 & 46 & 2 & 23 & 8 & 6 \\
\hline & & $\operatorname{Ar}(\%)$ & & 6 & 16 & 26 & 22 & 9 & 11 & 0 & 6 & 2 & 1 \\
\hline
\end{tabular}

At Bevoay, there are six stations of data sampling (Bevoayl, Bevoay2, Bevoay3, Bevoay4, Bevoay5 and Bevoay6), Tombomafana has two stations (Tombomafanal and Tombomafana2), Marofandroboka has four stations (Marofandrobokal, Marofandroboka2, Marofandroboka3 and Marofandroboka4), there are four data sampling stations in Antongomenabe (Antongomenabel, Antongomenabe2, Antongomenabe3 and Antongomenabe4) and the site of Makary contained four stations (MakaryI, Makary2, Makary3 and Makary4). Relative abundances (Ar) are presented in the last row.

Citation: Ramanantsalama RV,Andriamasimanana $\mathrm{RH}$, Andrianarimisa A, et al. Relationship between the abundance and distribution of the endemic fish Paretroplus dambabe in the north-western wetland of Madagascar and the effect of environmental parameters and the presence of other fish species. Biodiversity Int J. 20I8;2(2):I39-I45. DOI: I0.15406/bij.2018.02.00056 


\section{Influence of the physic-chemical and biological parameters}

According to the factor analysis, the $\mathrm{pH}$ and redox potential have high loadings in Factor 1; and the distance from the reed vegetation and dissolved oxygen are both correlated to the Factor 2 [Factor analysis: $\mathrm{X}^{2}(18)=19.37, \mathrm{P}=0.37$, Table 3]. Moreover, there are significant correlation between $\mathrm{pH}$ and redox potential (Spearman correlation: $\left.r_{s}=-0.918, P<0.001\right)$, and between the distance from the reed vegetation and dissolved oxygen (Spearman correlation: $\left.r_{s}=0 \cdot 609, P=0 \cdot 004\right)$. Therefore, there are both collinearity between $\mathrm{pH}$ and redox potential, and between the distance from the reed vegetation and dissolved oxygen. Thus, the redox potential and distance from the reed vegetation are chosen to complete the others independent variables for the next step of the analysis.

Regarding to the presence of $P$. dambabe and based on the MLR analysis, the effect of the Ars of O. niloticus, T. zillii, O. mossambicus, T. rendalli, $C$. carpio and redox potential on the presence of $P$. dambabe, is the best model (MLR: $\mathrm{F}_{6,13}=1.72, r^{2}=0 \cdot 186, \mathrm{P}=0 \cdot 194$ ). However, none of these predictors has a significant effect on the presence of $P$. dambabe (Table 4). Regarding to the Ars of $P$. dambabe, the effect of the Ars of A. sp., C. carpio, G. biocelatus, G. giuris, $O$. macrochir, O. niloticus, O. mossambicus, T. rendalli and T. zillii on the Ars of $P$. dambabe, is the best model (MLR: $\mathrm{F}_{6,13}=77.72, \mathrm{r}^{2}=0.97$, $\mathrm{P}<0.001)$. The Ars of $P$. dambabe is significantly affected by all the predictors within this model (Table 4).

Table 3 Correlation between independent variables and generated factors obtained from factor analysis method

\begin{tabular}{|c|c|c|c|c|c|c|c|c|c|c|}
\hline & Factor I & Factor 2 & Factor 3 & Factor 4 & Factor 5 & Factor 6 & Factor 7 & Factor 8 & Factor 9 & Factor 10 \\
\hline $\mathrm{n}$ total & 0.257 & & -0.205 & 0.411 & 0.284 & 0.174 & $0.560^{*}$ & 0.37 & 0.289 & 0.107 \\
\hline rs & & & & & & $0.937^{*}$ & & & & 0.154 \\
\hline distance & -0.48 & $0.697^{*}$ & & & 0.201 & -0.105 & 0.125 & -0.213 & & -0.111 \\
\hline $\mathrm{T}$ & -0.124 & -0.238 & & & & & & 0.227 & $0.877^{*}$ & \\
\hline $\mathrm{pH}$ & $0.980^{*}$ & & & & & & & 0.107 & & \\
\hline DO & -0.151 & $0.672^{*}$ & & & 0.126 & -0.176 & 0.119 & & & -0.248 \\
\hline Turb & -0.382 & 0.334 & $0.501 *$ & & 0.223 & & & & 0.393 & -0.203 \\
\hline$E$ & $0.966 *$ & & & & & & & & & \\
\hline C & $0.824^{*}$ & -0.206 & -0.194 & & -0.207 & & -0.292 & 0.245 & -0.216 & \\
\hline abomoss & & -0.149 & & & 0.296 & $0.511 *$ & 0.391 & -0.372 & -0.22 & -0.48 \\
\hline abomacr & -0.242 & -0.166 & -0.408 & 0.486 & $0.527 *$ & -0.164 & -0.194 & -0.132 & 0.129 & 0.361 \\
\hline abonilo & & -0.206 & & -0.273 & 0.101 & -0.113 & 0.138 & $0.878^{*}$ & 0.244 & \\
\hline abtrend & 0.156 & -0.268 & -0.139 & & $0.910 *$ & -0.203 & & -0.121 & & \\
\hline abtzill & & $0.964^{*}$ & & & & & & & -0.166 & 0.129 \\
\hline abccarp & 0.15 & -0.113 & & & & 0.151 & 0.161 & & -0.105 & $0.804 *$ \\
\hline abasp & & & $0.987^{*}$ & & & & & & & \\
\hline abggiur & -0.114 & & & $0.962^{*}$ & & & & 0.18 & & \\
\hline abgbioc & & -0.231 & -0.165 & 0.168 & & & $-0.785^{*}$ & & 0.114 & -0.122 \\
\hline
\end{tabular}

The factors $1-10$ are the created factors obtained from the factor analysis method. The null hypothesis that 10 factors are sufficient is not rejected [Factor analysis, $\left.X^{2}(18)=19.37, P=0.37\right]$. * indicates significant correlation between variable and factor

$\mathrm{X}^{2}$, chi-squared; $\mathrm{P}, \mathrm{p}$-value; $\mathrm{r}$, coefficient of correlation; $\mathrm{n}$ total, total number of caught individuals per station; rs, number of caught species per station; distance, distance to the reed vegetation; T, water temperature; $\mathrm{pH}$, hydrogen potential; $\mathrm{DO}$, dissolved oxygen; Turb, turbidity; E, redox potential; C, conductivity; abomoss, relative abundance per station (Ars) of Oreochromis mossambicus; abomacr, Ars of O. macrochir; abonilo; arsof O. niloticus; abtrend, ars of Tilapia rendalli; abtzill, arsof T. zillii; abccarp, Arsof Cyprinus carpio; abasp, arsof Ambassis sp.; abggiur, arsof Glossogobius giuris; abgbioc, arsof G. biocellatus

Table 4 Influence of independent variables on the presence and relative abundance per station (Ars) of Paretroplus dambabe

\begin{tabular}{lllllllll}
\hline Presence & & \multicolumn{7}{c}{ Relative abundance per station } \\
\hline Predictors & Estimate & $\mathbf{T}$ & $\mathbf{P}$ & Predictors & Estimate & $\mathbf{T}$ & $\mathbf{P}$ \\
\hline (Intercept) & $1.97 \mathrm{I}$ & 2.53 & $0.025^{*}$ & (Intercept) & 83.204 & 15.33 & $<0.00$ I $^{*}$ \\
abtrend & -0.01 & -1.68 & 0.117 & abomoss & -0.874 & -16.95 & $<0.00 I^{*}$ \\
abonilo & -0.014 & -2.04 & 0.063 & abomacr & -0.761 & -11.08 & $<0.00 I^{*}$ \\
abtzill & 0 & 0.03 & 0.979 & abtrend & -0.839 & -14.39 & $<0.00 I^{*}$ \\
\hline
\end{tabular}

Citation: Ramanantsalama RV,Andriamasimanana RH,Andrianarimisa A, et al. Relationship between the abundance and distribution of the endemic fish Paretroplus dambabe in the north-western wetland of Madagascar and the effect of environmental parameters and the presence of other fish species. Biodiversity Int J. 20I8;2(2):I39-I45. DOI: I0.15406/bij.2018.02.00056 
Table continued...

\begin{tabular}{lllllllll}
\hline Presence & & \multicolumn{7}{c}{ Relative abundance per station } \\
\hline Predictors & Estimate & $\mathbf{T}$ & $\mathbf{P}$ & Predictors & Estimate & $\mathbf{T}$ & $\mathbf{P}$ \\
\hline $\mathrm{E}$ & 0.008 & $\mathrm{I} .3$ & 0.218 & abccarp & -1.329 & -3.63 & $0.005^{*}$ \\
abccarp & 0.036 & 0.35 & $0.73 \mathrm{I}$ & abasp & -0.74 & $-9.8 \mathrm{I}$ & $<0.00$ I $^{*}$ \\
& & & & abggiur & -0.568 & -5.09 & $<0.00$ I $^{*}$ \\
& & & & abgbioc & -0.885 & -9.93 & $<0.00 I^{*}$ \\
& & & & & abonilo & -0.927 & -19.13 & $<0.00 I^{*}$ \\
\hline
\end{tabular}

Each effect of the independent variable is quantified by the estimate, $T$ value $(T)$ and $P$ value $(P)$. $\left.{ }^{(a b o v e ~} \mathrm{P}\right)$ indicates that the null hypothesis accordingly the response variable and predictor are independent, is rejected.

Abtrend, relative abundance per station (Ars) of Tilapia rendalli; abonilo, ars Oreochromis niloticus; abtzill, ars of Tilapia zillii; abomoss, ars of O. mossambicus; E, redox potential; abccarp, ars of Cyprinus carpio; abomacr, ars of O. macrochir; abasp, ars of Ambassis sp.; abggiur, ars of Glossogobius giuris; abgbioc, ars of G. biocellatus

\section{Discussion}

Water temperature of freshwater lake influences the other water physic-chemical parameters such as conductivity, turbidity, $\mathrm{pH}$, redox potential and dissolved oxygen. ${ }^{20-23}$ During the fieldwork, the water temperature in Marofandroboka is higher compared to the other sites (Table 1). The cause of this variation could be the erosion of the Mahavavy River. This latter is poured out and brings sediment to the lake mainly at the east part of Marofandroboka and decreases both the lake depth and the temperature variation between the deep and the surface water. ${ }^{12}$ According to the water classification of Bhatnagar $\&$ Devi, ${ }^{23}$ the water conductivity and $\mathrm{pH}$ of the lake are acceptable for freshwater fish. Conferring to the water redox potential at all data sampling stations, the water of the lake is categorized as reducer and water tends to be reducer when its pHvalue is greater than $7 .{ }^{20}$ During this study, the spatial variation of the redox potential and $\mathrm{pH}$ were collinear (Table 3). The collected data on $\mathrm{pH}$ by the SX736 is not really relevant; so, it is preferable to use the redox potential for the analysis. Otherwise, the dissolved oxygen rate is approximately constant throughout the lake and livable for freshwater fish (dissolved oxygen rate greater than $7 \mathrm{mg} \mathrm{l}^{-1}$ ) conforming to the findings of Rodier et al. ${ }^{24}$ The dissolved oxygen rate and the distance from the reed vegetation are collinear variables. The reed vegetation influences the dissolved oxygen rate; so, only the reed vegetation is retained for the modelling among these last collinear variables. According to the turbidity, data sampling sites are either slightly unclear or unclear. Marofandroboka, Tombomafana and Bevoay that have the highest value of turbidity, are directly linked to some watersheds especially the Mahavavy watershed (Figure 2) which is undergoing erosion. ${ }^{12}$ Nevertheless, the spatial variation of the physic-chemical parameters of the lake during the fieldwork did not affect neither the presence nor the abundance of $P$. dambabe.

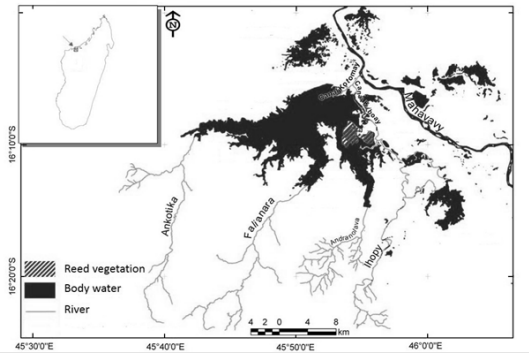

Figure 2 Hydrography of the Kinkony Lake. Reproduced with permission from. 12
The reed vegetation of Makary which is not directly affected by the erosion, gives suitable condition for fish especially those which use the reed to lay eggs like $P$. dambabe. However, this variable is not kept within the best MLR models neither with the model related to the presence of $P$. dambabe nor the one related to its Ars. Distance to the reed vegetation does not influence neither the presence nor the abundance of the target species. Actually, all sites have little discontinuous reed vegetation that $P$. dambabe can use and individuals of $P$. dambabe could not be obliged to go to Makary. Species number seems to be higher at Makary and Antongomenabe which are not directly threatened by the erosion and the rice-growing. Plus, the reed vegetation is located at Makary. Caught individual number is higher in Marofandroboka, Bevoay and Makary. Even if Makary gives appropriate condition for fish survival, dominant and influential species such as the member of the tilapiine sub family which are mostly the invasive species, could adapt themselves to the areas that are directly affected by erosion such as Marofandroboka and Bevoay. Nevertheless, neither species number per station nor total number of caught individuals per station do not show any relation to neither the presence nor the Ars of $P$. dambabe.

On the one hand, none of the predictors have a significant effect on the presence of $P$. dambabe. Paretroplus dambabe could be present in all sampling station. The pressure from human activities and from the invasive species especially the tilapiine cichlids which are either dominant or influential, do not yet affect the presence of $P$. dambabe in Kinkony Lake. On the other hand, the Ars of $P$. dambabe is negatively and significantly influenced by the Ars of all the other caught fish species. The effect of $C$. carpio which is classified as a very rare species, has the highest estimate followed by the effect of $O$. niloticus which is in turn a dominant species (Table 4). Actually, $C$. carpio is essentially an omnivorous fish like $P$. dambabe ${ }^{25}$ and could be in competition with $P$. dambabe. Like the tilapiine cichlids, $C$. carpio are known to have negative impact on the aquatic plant that could be used as support for the eggs of $P$. dambabe. Species within the genera Oreochromis and Tilapia are herbivorous. ${ }^{26-33}$ The member of these last genera could eat the eggs of $P$. dambabe when they consume the aquatic plant. Moreover, the fact that Oreochromis genus are mouth brooder, ${ }^{34,35}$ makes them a competitive groups compared to P. dambabe. Previous study found that when the resource is restricted, O. mossambicus feed on both small size fish and fish eggs. ${ }^{3,36,37}$ Species of the genus Glossogobius are carnivorous and the two species of Glossogobius in Kinkony Lake are bottom-feeding fishes. ${ }^{38}$ Glossogobius biocelatus which is classified as very rare species and G. giuris which is a rare species, could prey on the juvenile of

Citation: Ramanantsalama RV,Andriamasimanana RH,Andrianarimisa A, et al. Relationship between the abundance and distribution of the endemic fish Paretroplus dambabe in the north-western wetland of Madagascar and the effect of environmental parameters and the presence of other fish species. Biodiversity Int J. 2018;2(2):I39-I45. DOI: I0.15406/bij.2018.02.00056 
P. dambabe. The negative effect of $A$. sp. on $P$. dambabe could be explain by the fact that like all the species within the genus Ambassis, A. sp. could be probably omnivorous with carnivorous tendency. ${ }^{3}$ So, A. sp. could be both in competition and predator of $P$. dambabe.

Thus, the manager of the protected area of the Mahavavy-Kinkony Complex should continue the ecological monitoring of the lake and sample data on the evolution of each physic-chemical and biological parameters especially the ones that influence the abundance of $P$. dambabe. Climate change can perturb the environmental parameters of Kinkony Lake and could disturb native fish species compared to the invasive species. The absence of data from the far south of the lake limited the conclusion of this study. In addition, collected temperature during this study represents only the temperature of the water in the surface. Furthermore, data on the lake depth and salinity are useful to measure the effect of the watershed erosion and the ricegrowing in the shore. Then, nets used during the field do not reach the bottom of the lake and could affect the probability of capture of bottom-feeding fish compared to pelagic fish. Also, used nets during this study can only catch individual that is between 4 and $25 \mathrm{~cm}$ in length. So, it cannot capture any individual of Madagascar round herring Pellonulops madagascariensis which is a small size species. Paretroplus dambabe is also threatened by Pe. Madagascariensis fishing. During the fieldwork, $P$. dambabe was seen captured by the seine for Pe. madagascariensis but $P$. dambabe is not targeted by any fishermen. Finally, data sampling was performed at the end of the austral winter and before the closure of the fishing period. It will be interesting to compare the findings of this study to the collected data in the end of austral summer or in the beginning of the fishing period.

\section{Acknowledgements}

We thank Asity Madagascar association for granting us permission to perform the data sampling. We are grateful to Mrs. Voninavoko Raminoarisoa, National Coordinator of Asity Madagascar, and Mr. Rivo Rabarisoa, Wetland Coordinator of Asity Madagascar. The Zoology and Animal Biodiversity, University of Antananarivo helped us with different administrative aspects. We are thankful to Mr. Nirina Clarice, Mr. Solofoson Randrianjatovo, Andrianarijaona Rakotonarivo and all the local people who supported us with logistic aspects during the fieldwork. Also, we show our appreciation to the $\mathrm{R}$ core team that allows us to perform all the data analysis for free.

\section{Conflict of interest} article.

Authors declare there is no conflict of interest in publishing the

\section{References}

1. Arnoult J. Sur une nouvelle espèce de poisson malgache (CICHLIDAE) Paretroplus kieneri n. sp. Bulletin du Muséum National d'Histoire Naturelle Zoologie 1960;2:305-307.

2. Kiener A, Maugé M. Contributions à l'étude systématique et écologique des poissons Cichlidae endémiques de Madagascar. Mémoires du Muséum National d'Histoire Naturelle 1966;40(2):52-97.

3. Hutchison M, Sarac Z, Norris A. Mozambique tilapia: The potential for Mozambique tilapia Oreochromis mossambicus to invade the MurrayDarling Basin and the likely impacts: a review of existing information. Canberra City: Murray-Darling Bassin Authority; 2011.

4. Rham P de, Nourissat JC. The endemic cichlids of Madagascar.Barcelona: Sagrafic SL; 2004.
5. Andriamasimanana $\mathrm{RH}$, Rasolomanana $\mathrm{EH}$, Cameron A, et al. Etude des impactes écologiques du dynamisme spatio-temporel des habitats naturels sur la faune menacée du Complexe Zones Humides Mahavavy-Kinkony, Madagascar. Madagascar Conservation \& Development 2013;8:86-90.

6. Wohlfarth GW, Hulata G. Applied genetics of tilapias. Manila: International Center for Living Aquatic Resources Management; 1983.

7. Sardella BA, Matey V, Brauner CJ. Coping with multiple stressors physiological mechanisms and strategies in fishes of the Salton Sea. Lake and Reservoir Management. 2007;23(5):518-527.

8. Frei M, Khan MAM, Razzak MA, et al. Effects of a mixed culture of common European carp, Cyprinus European carpio L., and Nile tilapia, Oreochromis niloticus (L), on terrestrial arthropod population, benthic fauna, and weed biomass in rice fields in Bangladesh. Biological Control 2007;41:207-213.

9. Lintermans M. Fishes of the Murray-Darling basin: an introductory guide. Murray-Darling Basin: Murray-Darling Basin Authority; 2007.

10. Hutchison M, Butcher A, Kirkwood J, et al. Mesoscale movements of small and medium-sized fish in the Murray-Darling Basin. MurrayDarling Basin: Murray-Darling Basin Commission; 2008.

11. Conservation Breeding Specialist Group. Evaluation et Plans de Gestion pour la Conservation (CAMP) de la Faune de Madagascar: Lémuriens, Autres Mammifères, Reptiles et Amphibiens, Poissons d'eau douce et Evaluation de la Viabilité des Populations et des Habitats de Hypogeomis antimena (Vositse).Minnesota: CBSG, Apple Valley; 2002.

12. Andriamasimanana RH, Rabarimanana M. Analyses de la dégradation du lac Kinkony pour la conservation du Complexe des Zones Humides Mahavavy - Kinkony, Région Boeny, Madagascar. Madagascar Conservation \& Development. 2011;6(1):22-28.

13. Asity Madagascar. Plan d'Aménagement et de Gestion (PAG) Complexe Zones Humides Complexe Mahavavy-Kinkony Région Boeny. Madagascar; 2014.

14. Jolly GM. Explicit estimates from capture-recapture with both death and immigration. Stochastic model. Biometric. 1965;52:225-247.

15. Dytham C. Choosing and Using Statistics: A Biologist's Guide. Oxford: Osney Mead; 1999.

16. Crawley MJ. The $R$ book. John Wiley \& Sons Ltd, West Sussex: The Atrium,Southern Gate, Chichester; 2007.

17. Gardener M. Multiple Regression. Gardener's own; 2013.

18. Core Team R. R: a language and environment for statistical computing. R Foundation for Statistical Computing, Vienna. The R Project for Statistical Computing; 2013.

19. IBM Corporation. Spearman correlation (crosstabulations algorithms). IBM Knowledge Center; 2012.

20. Michard G. Signification du potentiel redox dans les eaux naturelles. Mineralium Deposita. 1967;2(1):34-36.

21. Adeyemi SO. Study of some physico-chemical parameters and their effect on potential fish yield in Gbedikere Lake, Bassa, Kogi State, Nigeria. Pakistan Journal of Nutrition. 2011;10(5):475-479.

22. BEEST. Proposition d'une stratégie de surveillance des paramètres physico-chimiques pour les estuaires de La Seine, de La Loire et de La Gironde, Bon Etat écologique des grands Estuaires; 2011.

23. Bhatnagar A, Devi P. Water quality guidelines for the management of pond fish culture. International Journal of Environmental Sciences. 2013;3(6):1980-1997.

24. Rodier JJG, Kova CEJ, Laporte N. Analyse de l'eau: Eaux naturelles, eaux résiduelles, eau de mer.Bordeau; 1994. 
25. Ranson SP. L'alimentation de la carpe commune (Cyprinus carpio) dans son biotope et en élevage. Paris, France: Ecole Nationale Véterinaire d'Alfort; 2003.

26. Arnoult J. Première note sur les Tilapia (Poissons) importés à Madagascar Le Naturaliste Malgache. 1953;5(2):221-224.

27. Fish GR. Food of tilapia in east Africa. East African Fisheries Research Organization (EAFRO), Uganda; 1955. p. 58-89.

28. Lowe-McConnell RH. Observations on the biology of Tilapia nilotica Linné in East African waters (Pisces: Cichlidae). Revue de Zoologie et de Botanique Africaines. 1958;57:129-170.

29. Blache J. Les poissons du lac Tchad et du bassin adjacent du Mayo Kebb. Mémoire, ORSTOM; 1964. p. 239-241.

30. Moriarty DJ, Moriarty CM. The assimilation of carbon from phytoplankton by two herbivorous fishes: Tilapia nilotica and Haplochromis nigripinnis. Journal of Zoology. 1973;171:41-45.

31. Beveridge MCM, Begum M, Frerichs GN, et al. The ingestion of bacteria in suspension by the tilapia Oreochromis niloticus. Aquaculture. 1989;81(3-4):373-378
32. Getachew $\mathrm{T}$, Fernando $\mathrm{CH}$. The food habits of an herbívoras fish (Oreochromis niloticus L.) in lake Awasa, Ethiopia. Hydrobiologia. 1989;174(3):195-200.

33. Mukankomeje R, Laviolette F, Descy JP. Régime alimentaire de Tilapia, Oreochromis niloticus, du Lac Muhazi (Rwanda). Annales de Limnologie. 1994;30(4):297-312.

34. Arnoult J. Reproduction du Tilapia nigra. Le Naturaliste Malgache. $1954 ; 6: 85-86$

35. Arnoult J. Poissons des eaux douces. Tananarive: Institut de Recherche Scientifique de Madagascar; 1959

36. Arthington AH, Blühdorn R. Distribution, genetics, ecology and status of the introduced cichlid, Oreochromis mossambicus, in Australia. Communications of the International Association of Theoretical and Applied Limnology. 1994;24(1):53-62.

37. Fuselier L. Impacts of Oreochromis mossambicus (Perciformes: Cichlidae) upon habitat segregation among cyprinodontids (Cyprinodontiformes) of a species flock in Mexico. Revista de Biologia Tropical. 2001;49(2):647-656.

38. Kiener A. Poissons, pêche et pisciculture à Madagascar. Nogent sur Marne: Centre Technique Forestier Tropical; 1963. 